\title{
PENETAPAN KADAR PIPERIN DALAM EKSTRAK BUAH LADA HITAM (Piper nigrum Linn.) MENGGUNAKAN LIQUID CHROMATOGRAPHY TANDEM MASS SPECTROMETRY (LC-MS/MS)
}

\author{
${ }^{1}$ Alifia Putri Febriyanti, ${ }^{2}$ Siti Jazimah Iswarin, ${ }^{3}$ Susanti \\ ${ }^{1}$ Jurusan Farmasi Fakultas Kedokteran dan Ilmu Kesehatan UIN Alauddin Makassar \\ ${ }^{2,3}$ Program Studi Farmasi Fakultas Kedokteran Universitas Brawijaya, Malang \\ email : alifia.putri@uin-alauddin.ac.id
}

\begin{abstract}
ABSTRAK
Pemanfaatan tanaman sebagai obat sudah mulai berkembang pesat di dunia termasuk di Indonesia seiring dengan pemikiran back to nature, salah satu tanaman yang sering digunakan sebagai obat adalah buah lada hitam (Piper nigrum Linn.). Piperin merupakan komponen utama dan zat berkhasiat yang terkandung dalam buah lada hitam yang memiliki aktivitas sebagai antidiare. Tujuan dari penelitian ini untuk mengetahui kadar piperin dalam ekstrak etanol 96\% buah lada hitam. Metode ekstraksi yang digunakan adalah soxhlet dalam pelarut etanol 96\%. Analisis piperin dilakukan dengan analisis kualitatif dengan kromatografi lapis tipis (KLT) menghasilkan noda kuning setelah disemprot dragendorf dan berwarna biru gelap pada pengamatan Uv-Vis dengan panjang gelombang $365 \mathrm{~nm}$ dengan harga $\mathrm{Rf}$ ekstrak 0.49 dan $\mathrm{Rf}$ piperin 0.5. Analisis kuantitatif dengan LC-MS/MS menghasilkan kadar piperin sebesar 26\%. Sebelum dilakukan analisis kuantitatif, perlu dilakukan metode validasi dengan parameter, antara lain: linieritas memiliki persamaan regresi y $=1,981,691.1333 x+561,445.0000$ dan koefisien korelasi (R2) 0.9973, LOD dengan nilai $0.14 \mathrm{ppm}$ dan LOQ $0.44 \mathrm{ppm}$, akurasi (\%recovery) berkisar antara 95.90 $100.77 \%$, presisi (\% KV) antara $0.02-1.84 \%$, serta selektivitas (RT) antara $2.47-2.49$. Hasil parameter validasi memenuhi syarat sehingga kadar piperin yang diperoleh dengan LC-MS/MS dinyatakan akurat, spesifik, dan tepat.
\end{abstract}

Kata Kunci: Buah lada hitam (Piper nigrum Linn.), piperin, KLT, metode validasi, LCMS/MS

\begin{abstract}
The utilization of medicinal plants have started growing rapidly in the world, including in Indonesia, along with the thinking back to nature, one of the plants that are often used as a medicine is black pepper fruit (Piper nigrum Linn.). Piperine is a major compound and potent substances contained in black pepper fruit as antidiarrheal activity. The aim of this study was to determine levels of piperine in $96 \%$ ethanol extract of black pepper fruit. The extraction method used Soxhlet in $96 \%$ ethanol as solvent. Analysis of piperine using qualitative analysis by thin layer chromatography (TLC) produces yellow stain after being sprayed by dragendorf and dark blue on observation Uv-Vis $365 \mathrm{~nm}$ with Rf extract value 0.49 and $\mathrm{Rf}$ piperine value 0.5. Quantitative analysis using LC - MS produces piperine levels at $26 \%$. Before quantitative analysis, validation method needs to be done with the parameters, among others: linearity have regression equation $\mathrm{y}=$ has $1,981,691.1333 \mathrm{x}+$ $561,445.0000$ and correlation coefficient (R2) of 0.9973, LOD and LOQ at 0.14 and 0.44 ppm, accuracy value (\% recovery) between $95.90-100.77 \%$, precision value (\% KV) between $0.02-1.84 \%$, and selectivity (RT) between $2.47-2.49$. The results of the validation parameters are eligible so that piperine levels were obtained by LC - MS declared accurate, specific, and precise.
\end{abstract}

Keywords: Black pepper fruit (Piper nigrum Linn.), piperine, TLC, validation method, $L C$ $M S / M S$ 


\section{PENDAHULUAN}

Penggunaan obat tradisional telah berkembang secara luas dan sudah cukup terkenal di berbagai penjuru dunia. Penggunaan obat tradisional ini tidak hanya digunakan untuk perawatan kesehatan yang utama oleh masyarakat miskin di negaranegara berkembang, tetapi juga telah digunakan di negara-negara yang sebagian besar penduduknya menggunakan obat konvensional dalam sistem perawatan kesehatan nasional. Pada saat ini, penggunaan obat-obatan tradisional sudah dikenal di seluruh dunia. Oleh karena itu, pemerintah dan farmasis harus turut serta dalam prosedur keamanan, kemanjuran dan pengendalian kualitas obat-obat tradisional (WHO, 2000). Salah satu tanaman yang sering digunakan sebagai obat adalah buah lada hitam (Piper nigrum Linn.).

Tanaman lada hitam secara luas tumbuh di tempat dengan iklim yang tropis dengan kelembapan yang cukup. Bagian tanaman lada hitam yang sering dimanfaatkan adalah buah yang telah dikeringkan. Buah lada hitam dikenal sebagai "King of Spices" karena memiliki rasa yang pedas dan beraroma khas yang sangat kuat dari semua rempah-rempah di dunia (Shamina,A. 2001).

Buah lada hitam yang termasuk dalam keluarga Piperaceae merupakan salah satu jenis tanaman obat yang banyak tumbuh di Negara tropis termasuk Indonesia dan sering digunakan sebagai bumbu masakan. Buah lada hitam sering dimanfaatkan untuk mengobati diare, antiinflamasi, hepatoprotektan, dan perut mulas (Ahmad, N. et al. 2012). Kandungan utama dari buah lada hitam adalah piperin. Metode ekstraksi yang dipilih adalah soxhlet karena senyawa piperin memiliki sifat yang stabil terhadap panas.

Piperin bertanggung jawab terhadap tingkat rasa pedas di dalam buah lada hitam, bersama dengan kavisin. Piperin memiliki warna kuning yang berbentuk jarum, yang sukar larut dalam air dan mudah larut dalam etanol, eter, dan kloroform. Kelarutan piperin dalam etanol dikenal sebagai "pepper-like taste" (Patil, K. 2011). Piperin bila dikecap mula-mula tidak berasa, lama-lama tajam menggigit. Apabila piperin terhidrolisis akan terurai menjadi piperidin dan asam piperat. Berat molekul piperin sebesar 285,3377 (Istiqomah. 2013). Titik didih yang dimiliki piperin sebesar $127^{\circ} \mathrm{C}$ (Shamkuwar, B., et al. 2013).

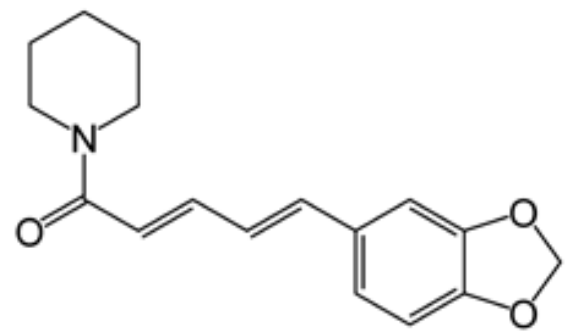

Gambar 1. Struktur kimia piperin (Patil, et al. 2011) Nama IUPAC: 1-[5-(1, 3benzodioxol- 5-yl)-1-oxo-2,4-pentadienyl] piperidine

Piperin bersifat tahan panas karena memiliki titik didih yang cukup tinggi (Harborne, J. B., 1987). Apabila terkena 
cahaya akan terjadi fotoisomerisasi membentuk isomer isochavisin (trans-cis), isopiperin (cis-trans), dan piperin (transtrans) (Anwar, C. 1994).

Senyawa fitokimia lain dalam buah lada hitam yang juga memiliki peran penting selain piperin, yaitu piperamida, piperamin, piperisida, sarmentosin, sarmentin (Ahmad, N. et al. 2012). Derivat-derivat tersebut memiliki struktur kimia seperti yang ditunjukkan oleh gambar 2 di bawah ini:

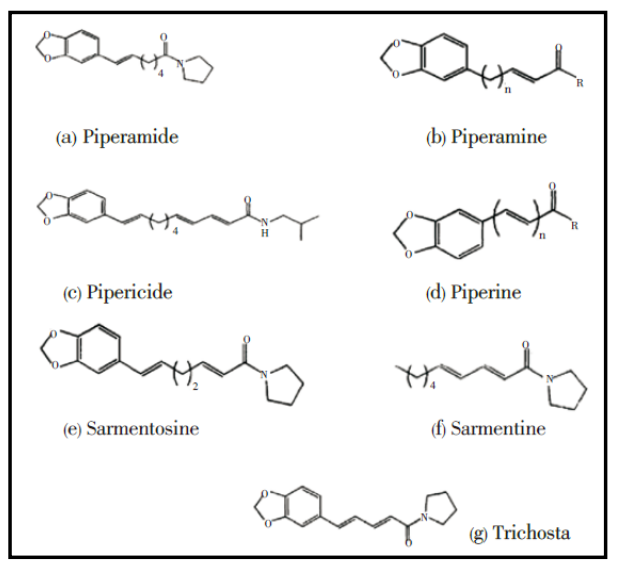

Gambar 2. Struktur kimia metabolit sekunder buah lada hitam (Ahmad, N. et al. 2012)

Dalam dunia pengobatan, buah lada hitam biasa digunakan untuk mengatasi gangguan pencernaan seperti racun pada usus besar yang menyebabkan diare. Buah lada hitam juga biasa digunakan untuk mengatasi gangguan pernafasan termasuk flu, demam, dan asma. Di Afrika Barat, buah lada hitam digunakan untuk mengobati bronchitis, gastritis, rematik, dan sebagai agen antivirus Ahmad, N. et al. 2012).

Piperin dalam buah lada hitam dapat menstimulasi enzim pencernaan pada pankreas dan usus halus serta dapat meningkatkan sekresi asam bilirubin jika diberikan peroral. Metabolit sekunder yang terkandung dalam buah lada hitam berperan dalam menghambat infeksi yang disebabkan oleh mikroba, serangga dan hewan. Menurut beberapa penelitian ekstrak etanol $96 \%$ buah lada hitam memiliki potensial sebagai antiinflamasi, thermogenic action, stimulator hormon pertumbuhan, antitiroid, dan chemopreventive. Pada percobaan in vivo (pada tikus), piperin dapat mencegah dan mengurangi diare dengan memproduksi bermacam-macam minyak (castor oil) dan zat kimia yang dapat menurunkan dan mencegah penumpukan cairan intestinal ${ }^{2}$. Selain itu, piperin dapat menghambat atau membunuh bakteri (Escherichia coli) sebagai penyebab diare (Laurina, D., 2008).

Penelitian ini dilakukan untuk mengetahui kadar piperin di dalam ekstrak etanol $96 \%$ buah lada hitam. Kadar yang diperoleh dapat digunakan pada penelitian selanjutnya untuk mengetahui kegunaan buah lada hitam lebih terperinci.

\section{METODE PENELITIAN}

\subsection{Desain Penelitian}

Penelitian ini menggunakan desain eksperimen murni (true experimental design) yang dilakukan di laboratorium. Buah lada hitam diekstraksi secara soxhlet menggunakan pelarut etanol $96 \%$ teknis untuk mendapatkan ekstrak buah lada hitam salah satunya adalah piperin yang kemudian 
dilakukan analisis kuantitatif dengan LC MS.

\subsection{Tempat dan Waktu}

Penelitian ini dilaksanakan di Laboratorium Farmasi Fakultas Kedokteran Universitas Brawijaya, dan Laboratorium Teknik Kimia Politeknik Negeri Malang. Penelitian dilakukan pada bulan Januari hingga Februari 2015.

\subsection{Sampel Penelitian}

Pada penelitian ini menggunakan sampel serbuk simplisia buah lada hitam yang diperoleh dari UPT Materia Medica yang berada di Jalan Lahor Nomor 87, Kota Batu, Jawa Timur.

\subsection{Variabel Bebas}

Variabel bebas pada penelitian ini adalah ekstrak etanol 96\% buah lada hitam.

\subsection{Variabel Terikat}

Variabel terikat pada penelitian ini adalah kadar piperin dari buah lada hitam.

\section{HASIL DAN PEMBAHASAN}

Proses ekstraksi buah lada hitam dilakukan dengan metode soxhlet menggunakan pelarut etanol 96\% teknis. Piperin memiliki sifat yang tahan panas sehingga tidak rusak ketika dilakukan proses ekstraksi dengan soxhlet. Simplisia yang diekstrak ditimbang sebanyak 100 g yang dibagi menjadi 2 bagian, masing-masing ditimbang sebanyak 50 g menggunakan neraca analitik. Kedua serbuk simplisia tersebut dimasukkan ke dalam timbel yang sebelumnya sudah dibuat dari kertas saring berbentuk tabung. Timbel yang sudah berisi simplisia dimasukkan ke dalam klonsong soxhlet. Setelah itu ditambahkan pelarut sebanyak 1.5 kali tinggi timbel di dalam klonsong kemudian alat soxhlet dinyalakan untuk proses ekstraksi.

Proses ekstraksi dihentikan jika pelarut yang merendam timbel dalam klonsong sudah menjadi jernih (Gambar 4) dan proses ini berlangsung selama 8 jam. Pada proses ini dihasilkan ekstrak cair sebanyak 300ml kemudian disimpan dalam botol gelap.

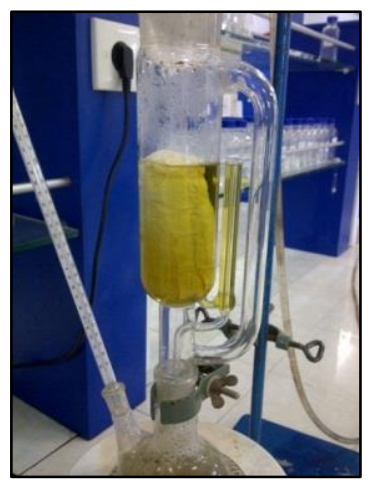

Gambar 3. Warna Pelarut Pekat

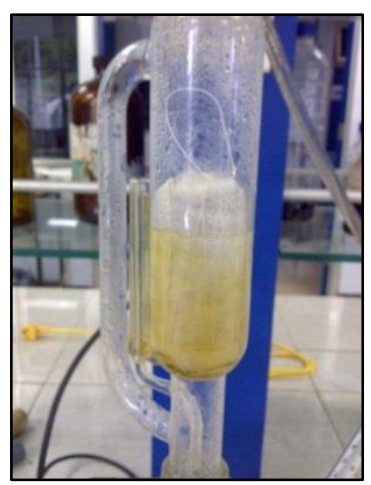

Gambar 4. Warna Pelarut Jernih

Ekstrak cair yang diperoleh kemudian dipekatkan dengan rotavapor pada suhu $60^{\circ} \mathrm{C}$ dengan kecepatan 70 rpm kemudian dioven pada suhu $40^{\circ} \mathrm{C}$ sampai mengental. Pada proses ini dihasilkan ekstrak kental dan kemudian dilakukan penimbangan pada 
neraca analitik. Ekstrak kental yang dihasilkan sebanyak $12.207 \mathrm{~g}$ dan diperoleh persentase rendemen $12.207 \%$. Kemudian dilakukan analisis kualitatif dengan KLT untuk mengetahui ada / tidaknya senyawa alkaloid (piperin) di dalam ekstrak etanol $96 \%$ buah lada hitam yang dibandingkan dengan standar. Prosedur analisis KLT diawali dengan pembuatan larutan standar piperin $1 \mathrm{mg} / 1 \mathrm{ml}$ metanol dan ekstrak kental buah lada hitam 30mg / 3ml metanol, menggunakan eluen dengan perbandingan toluene : etil asetat 70:30. Pada penelitian ini diamati noda senyawa piperin menggunakan sinar UV dengan panjang gelombang $365 \mathrm{~nm}$ berwarna biru gelap (Gambar 5), sedangkan noda senyawa piperin pada ekstrak setelah disemprot dragendorf menghasilkan warna kuning yang sejajar dengan standar kemudian dihitung nilai Rf noda senyawa piperin ekstrak terdapat pada 0.49 dan standar piperin terletak pada $\mathrm{Rf}=0.5($ Gambar 6$)$.

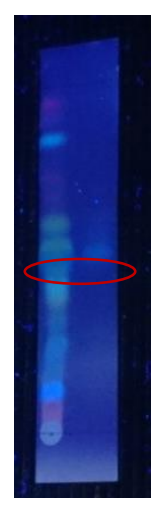

Gambar 5. Plat KLT pada UV 365 nm

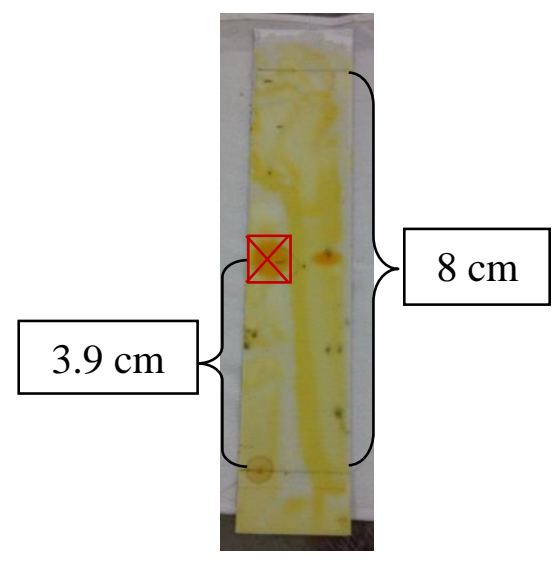

Gambar 6. Plat KLT secara visual Penetapan kadar piperin dengan LC - MS diperlukan proses validasi metode untuk memastikan metode tersebut akurat dan dapat digunakan sebagai metode penetapan kadar, sehingga kadar yang dihasilkan konsisten dan dapat dipercaya. Parameter-parameter yang perlu divalidasi, antara lain: linieritas, batas deteksi (LOD) dan batas kuantisasi (LOQ), selektivitas, akurasi, presisi (Gandjar, dkk. 2007).

Analisis linieritas dilakukan pada seri larutan standar piperin dengan konsentrasi $0.75 \mathrm{ppm}$, 1.50 ppm, 2.25 ppm, 3.00 ppm, dari analisis didapatkan persamaan regresi linier $\mathrm{y}=$ $1,981,691.1333 x+561,445.0000$ dengan koefisien korelasi $\left(\mathrm{R}^{2}\right)=0.9973$. Syarat minimum untuk linearitas adalah 0.996, jadi data ini sudah linier. Kurva linearitas dari persamaan garis tersebut terdapat pada

\section{Gambar 7.}




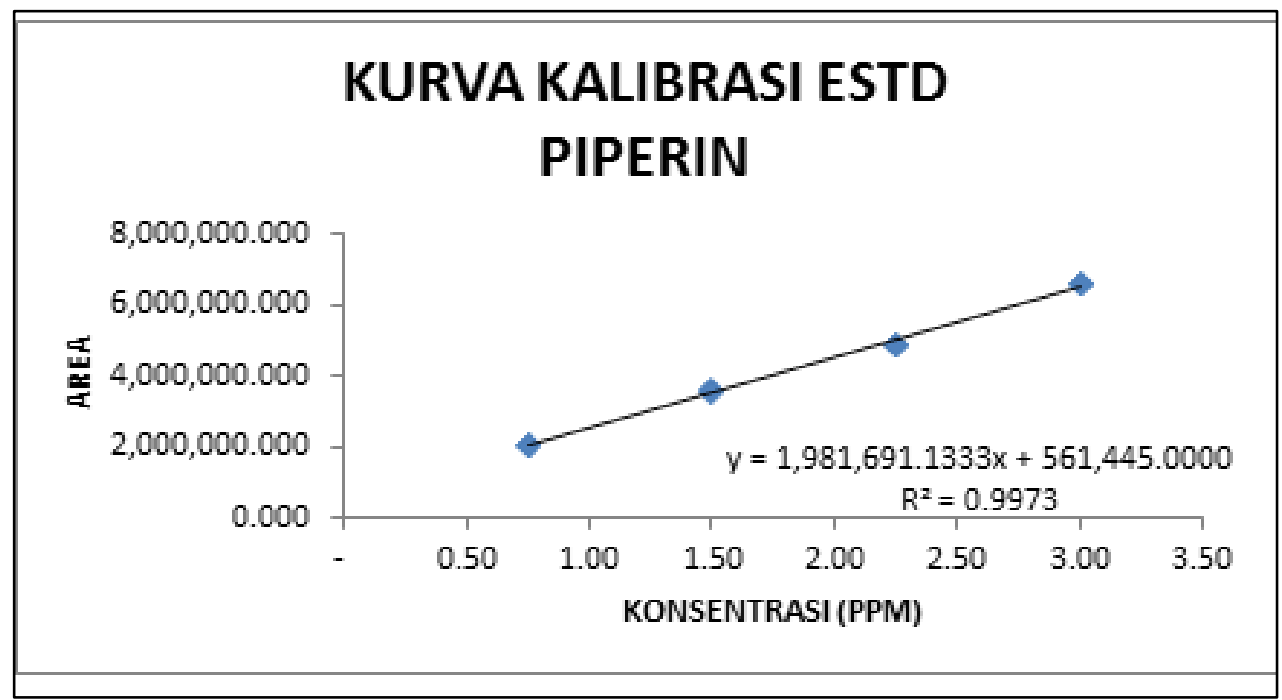

Gambar 7. Kurva Linearitas Piperin

Analisis batas deteksi dan batas kuantitasi presisi yang baik dan memenuhi syarat. Batas merupakan salah satu parameter metode deteksi yang diperoleh dari hasil validasi yang harus dilakukan untuk penganalisisan sebesar $0.14 \mathrm{ppm}$ dan batas mengetahui batas deteksi dan kuantitasi kuantitasi $0.44 \mathrm{ppm}$. Data mengenai analisis terendah dari sampel. Penganalisisan ini batas deteksi dan batas kuantitasi dapat dilihat bertujuan agar sampel yang analisis masih pada Tabel 1. dapat menghasilkan data dengan akurasi dan

Tabel 1. Hasil Analisis Batas Deteksi (LOD) dan Batas Kuantitasi (LOQ)

\begin{tabular}{|l|c|c|}
\hline Nama STANDARD & Kons. (PPM) & (Area) \\
\hline STANDARD 1 & 0.75 & $2,053,567.00$ \\
\hline STANDARD 1u & 0.75 & $2,092,474.00$ \\
\hline STANDARD 2 & 1.50 & $3,580,285.00$ \\
\hline STANDARD 2u & 1.50 & $3,555,236.00$ \\
\hline STANDARD 3 & 2.25 & $4,871,545.00$ \\
\hline STANDARD 3u & 2.25 & $4,881,997.00$ \\
\hline STANDARD 4 & 3.00 & $6,591,904.00$ \\
\hline STANDARD 4u & 3.00 & $6,589,919.00$ \\
\hline
\end{tabular}

\begin{tabular}{|l|l|}
\hline \multicolumn{1}{|c|}{ Parameter } & \multicolumn{1}{c|}{ Nilai } \\
\hline Standar Error & 86679.71242 \\
\hline Slope & 1981691.133 \\
\hline Limit deteksi (LOD) & $0.14 \mathrm{ppm}$ \\
\hline Limit kuantitasi (LOQ) & $0.44 \mathrm{ppm}$ \\
\hline
\end{tabular}


Analisis selektivitas dilakukan untuk terjadinya pemisahan piperin dari pengotor. mengetahui spesifisitas dari metode yang Pada analisis LC - MS hanya dihasilkan satu digunakan dalam menganalisis senyawa puncak, sehingga analisis selektivitas hanya piperin pada ekstrak etanol $96 \%$ buah lada berdasarkan waktu retensi (RT). Data hitam. Metode ini memenuhi syarat dalam mengenai analisis selektivitas dapat dilihat kemampuannya mendeteksi senyawa piperin pada Tabel 2.

pada retention time yang hampir sama serta

Tabel 2. Hasil Analisis Selektivitas

\begin{tabular}{|c|c|c|c|}
\hline Nama & Replikasi & Luas Area & Retention Time (RT) \\
\hline \multirow{3}{*}{ Sampel } & 1 & $2,934,167.00$ & 2.47 \\
\hline & 2 & $2,877,747.00$ & 2.47 \\
\hline & Rata-rata & $2,905,957.00$ & \\
\hline \multirow{3}{*}{ Larutan Baku 0.75 ppm } & 1 & $2,053,567.00$ & 2.47 \\
\hline & 2 & $2,092,474.00$ & 2.48 \\
\hline & Rata-rata & $2,073,020.50$ & \\
\hline \multirow{3}{*}{ Larutan Baku 1.50 ppm } & 1 & $3,580,285.00$ & 2.48 \\
\hline & 2 & $3,555,236.00$ & 2.48 \\
\hline & Rata-rata & $3,567,760.50$ & \\
\hline \multirow{3}{*}{ Larutan Baku 2.25 ppm } & 1 & $4,871,545.00$ & 2.48 \\
\hline & 2 & $4,881,997.00$ & 2.47 \\
\hline & Rata-rata & $4,876,771.00$ & \\
\hline \multirow{3}{*}{ Larutan Baku 3.00 ppm } & 1 & $6,591,904.00$ & 2.49 \\
\hline & 2 & $6,589,919.00$ & 2.48 \\
\hline & Rata-rata & $6,590,911.50$ & \\
\hline
\end{tabular}

Pada analisis akurasi dilakukan pada 4 Syarat hasil analisis akurasi nilai perolehan konsentrasi sampel yang berbeda, yaitu 0.75 kembali (\% recovery) secara umum adalah 80 ppm, $1.50 \mathrm{ppm}, 2.25 \mathrm{ppm}$, dan $3.00 \mathrm{ppm}$. $\quad-110 \%{ }^{8}$. Hasil analisis dapat dilihat pada Prosedur ini dilakukan pengulangan sebanyak Tabel 3. dua kali untuk masing-masing konsentrasi. 
Tabel 3. Hasil Analisis Akurasi

\begin{tabular}{|c|c|c|c|c|}
\hline Nama & Replikasi & Luas Area & $\begin{array}{c}\text { Kons. Terhitung } \\
(\mathbf{p p m})\end{array}$ & $\begin{array}{c}\% \\
\text { Recovery }\end{array}$ \\
\hline \multirow{3}{*}{$\begin{array}{l}\text { Larutan Baku } 0.75 \\
\text { ppm }\end{array}$} & 1 & $2,053,567.00$ & 0.75 & 99.47 \\
\hline & 2 & $2,092,474.00$ & 0.77 & 102.07 \\
\hline & Rata-rata & $2,073,020.50$ & 0.76 & 100.77 \\
\hline \multirow{3}{*}{$\begin{array}{l}\text { Larutan Baku } 1.50 \\
\text { ppm }\end{array}$} & 1 & $3,580,285.00$ & 1.51 & 100.63 \\
\hline & 2 & $3,555,236.00$ & 1.50 & 99.79 \\
\hline & Rata-rata & $3,567,760.50$ & 1.505 & 100.21 \\
\hline \multirow{3}{*}{$\begin{array}{l}\text { Larutan Baku } 2.25 \\
\text { ppm }\end{array}$} & 1 & $4,871,545.00$ & 2.16 & 95.78 \\
\hline & 2 & $4,881,997.00$ & 2.16 & 96.01 \\
\hline & Rata-rata & $4,876,771.00$ & 2.16 & 95.90 \\
\hline \multirow{3}{*}{$\begin{array}{l}\text { Larutan Baku } 3.00 \\
\text { ppm }\end{array}$} & 1 & $6,591,904.00$ & 3.02 & 100.51 \\
\hline & 2 & $6,589,919.00$ & 3.01 & 100.47 \\
\hline & Rata-rata & $6,590,911.50$ & 3.015 & 100.49 \\
\hline
\end{tabular}

Analisis presisi dilakukan pada 4 konsentrasi sampel yang berbeda, yaitu 0.75 ppm, 1.50 ppm, 2.25 ppm, dan 3.00 ppm diulangi sebanyak dua kali untuk masing-masing konsentrasi syarat hasil analisis presisi adalah persentase simpangan baku relatif atau koefisien variasi (KV) dengan nilai antara 1 2\% (Gandjar, dkk. 2007). Hasil analisis presisi dapat dilihat pada Tabel 4.

Tabel 4. Hasil Analisis Presisi

\begin{tabular}{|c|c|c|c|c|c|}
\hline Nama & Replikasi & Luas Area & $\begin{array}{c}\text { Kons. Terhitung } \\
\text { (ppm) }\end{array}$ & $\begin{array}{r}\text { Standar } \\
\text { Deviasi }\end{array}$ & $\begin{array}{c}\% \\
\mathrm{KV}\end{array}$ \\
\hline \multirow{3}{*}{$\begin{array}{l}\text { Larutan Baku } \\
0.75 \mathrm{ppm}\end{array}$} & 1 & $2,053,567.00$ & 0.75 & \multirow{3}{*}{0.0138} & \multirow{3}{*}{1.85} \\
\hline & 2 & $2,092,474.00$ & 0.77 & & \\
\hline & Rata-rata & $2,073,020.50$ & 0.76 & & \\
\hline \multirow{3}{*}{$\begin{array}{l}\text { Larutan Baku } \\
1.50 \mathrm{ppm}\end{array}$} & 1 & $3,580,285.00$ & 1.51 & \multirow{3}{*}{0.0089} & \multirow{3}{*}{0.59} \\
\hline & 2 & $3,555,236.00$ & 1.50 & & \\
\hline & Rata-rata & $3,567,760.50$ & 1.505 & & \\
\hline \multirow{3}{*}{$\begin{array}{l}\text { Larutan Baku } \\
2.25 \mathrm{ppm}\end{array}$} & 1 & $4,871,545.00$ & 2.16 & \multirow{3}{*}{0.0037} & \multirow{3}{*}{0.17} \\
\hline & 2 & $4,881,997.00$ & 2.16 & & \\
\hline & Rata-rata & $4,876,771.00$ & 2.16 & & \\
\hline
\end{tabular}




\begin{tabular}{|l|c|c|c|c|c|}
\hline \multirow{2}{*}{$\begin{array}{l}\text { Larutan Baku } \\
3.00 \mathrm{ppm}\end{array}$} & 1 & $6,591,904.00$ & 3.02 & \multirow{2}{*}{0,0007} & \multirow{2}{*}{0.02} \\
\cline { 2 - 4 } & 2 & $6,589,919.00$ & 3.01 & & \\
\cline { 2 - 4 } & Rata-rata & $6,590,911.50$ & 3.015 & & \\
\hline
\end{tabular}

Setelah melakukan validasi metode penetapan kadar piperin dan persyaratan setiap parameter terpenuhi, maka dapat menentukan kadar piperin. Penentuan kadar piperin dilakukan dengan penganalisisan sampel ekstrak yang diulangi sebanyak dua kali,

Tabel 5. Perhitungan Kadar Piperin Ekstrak Etanol 96\% Buah Lada Hitam

\begin{tabular}{|c|c|c|c|c|c|c|}
\hline $\begin{array}{c}\text { Nama dan } \\
\text { Berat Sampel } \\
(\mathbf{g})\end{array}$ & Luas Area & $\begin{array}{c}\text { Kons. } \\
\text { Terhitung } \\
(\boldsymbol{\mu g} / \mathbf{m l})\end{array}$ & Berat $(\boldsymbol{\mu g})$ & $\begin{array}{c}\text { Berat } \\
(\mathbf{g})\end{array}$ & Kadar & $\begin{array}{c}\% \\
\text { Kadar }\end{array}$ \\
\hline \multirow{2}{*}{ Sampel 0.5012} & $2,934,167.00$ & 1.20 & $131,843.17$ & & \multirow{2}{*}{0.26} & 26 \\
\cline { 2 - 5 } & $2,877,747.00$ & 1.17 & $128,708.12$ & 0.13 & 0.26 & \\
\hline Rata-rata & $2,905,957.00$ & 1.18 & $130,275.64$ & & \\
\hline
\end{tabular}

\section{KESIMPULAN DAN SARAN}

\subsection{Kesimpulan}

Ekstrak etanol $96 \%$ buah lada hitam mengandung senyawa piperin dengan kadar sebesar 26\% menggunakan analisis LC - MS. Metode validasi yang dihasilkan, antara lain: akurasi (\% recovery) $99.50-100.77 \%$, presisi (\% KV) $0.02-1.85 \%$, selektivitas (RT) 2.47 - 2.49, persamaan linieritas $\mathrm{Y}=$ $1,981,691.1333 x+561,445.0000$ dengan $\mathrm{R}^{2}$ $=0.9973$. Nilai LOD 0.14 ppm dan LOQ 0.44 ppm.

\subsection{Saran}

1. Perlu dilakukan penelitian lebih lanjut terkait kadar piperin pada ekstrak buah kemudian dihitung rata-rata untuk dihitung kadar yang diperoleh. Kadar piperin ekstrak etanol $96 \%$ buah lada hitam dalam penelitian ini sebesar 26\%. Hasil perhitungan kadar dapat dilihat pada Tabel 5 
BPOM, 2000. Parameter Standar Umum Ekstrak Tumbuhan Obat. BPOM, hal. 1; 7; 9-12

Chithra, S., et al. 2014. LC-MS/MS Based Identification of Piperine Production by Endophytic Mycosphaerella sp. PF13 from Piper nigrum. Springer Science. New York

Dai, J., et al. 2010. Plant Phenolics: Extraction, Analysis and Their Antioxidant and Anticancer Properties. Molecules. Kentucky, USA, p. 7314-7318

Depkes RI. 1980. Materia Medika Indonesia. Jilid II. Jakarta. Hal. 94-98

Gandjar, dkk. 2007. Kimia Farmasi Analisis. Pustaka Pelajar. Yogyakarta

Ginting, M.K. 2012. Validasi Mertode LCMS/MS untuk Penentuan Senyawa Asam Trans, Trans-Mukonat, Asam Hippurat, Asam 2-Metil Hippurat, Asam 3-Metil Hippurat, Asam 4-Metil Hippurat dalam Urin sebagai Biomarker Paparan Benzena, Toluena, dan Xilena. Skripsi. Jakarta: Program Studi Kimia Fakultas Matematika dan Ilmu Pengetahuan Alam Universitas Indonesia Depok.

Hamrapurkar, P.D., et al. 2011. Quantitative Estimation of Piperine in Piper nigrumI and Piper longum Using High Performance Thin Layer Chromatography. Journal of Applied Science 01 (03): 117120

Handa, S., et al. Extraction Technologies for Medicinal and Aromatic Plants. United Nations Industrial Development Organization and the International Centre for Science and High Technology, p. 2122; 29-33

Harborne, J. B., 1987. Metode Fitokimia. Penerbit ITB. Bandung. Hal. 6

Istiqomah. 2013. Perbandingan Metode Ekstraksi Maserasi dan Sokletasi Terhadap Kadar Piperin Buah Cabe Jawa (Piperis retrofracti fructus). Skripsi tidak diterbitkan. Jakarta: Fakultas Kedokteran dan Ilmu Kesehatan Universitas Islam Negeri Syarif Hidayatulloh

Khajuria, RK., et al. 2013. Concentration Dependent Electrospray Ionization Mass Spectrometry And Tandem Mass
Spectrometry (MS/MS) Studies On Piperine And Its Analogues. Springerplus, 2:427

Laurina, D., 2008. Isolasi Piperin dari Lada Hitam dan Sintesis Asam Piperat serta Uji Aktivitasnya sebagai Antibakteri Escherichia coli. (Abstrak). Universitas Negeri Malang. Malang

Menteri Kesehatan Republik Indonesia. 2009. Farmakope Herbal Indonesia. Edisi Pertama. Jakarta

Nohong. 2009. Skrining Fitokimia Tumbuhan Ophiopogon jaburan Lodd dari Kabupaten Kolaka Provinsi Sulawesi Tenggara. Jurnal Pembelajaran Sains. Vol. 5 No.2. Kendari

Patil, K. 2011. Role of Piperine As A Bioavailability Enhancer. Institute of Pharmacy. University Bhanpur. India

Rahman, M.N. 2009. Aktivitas Antibakteri Senyawa Hasil Biotransformasi Kurkumin Oleh Mikrob Endofit Asal Kunyit. Skripsi tidak diterbitkan. Bogor: Fakultas Matematika dan Ilmu Pengetahuan Alam Institut Pertanian Bogor.

Ramadhan, A.E., Phaza, H.A. 2010. Pengaruh Konsentrasi Etanol, Suhu dan Jumlah Stage pada Ekstraksi Oleoresin Jahe (Zingiber officinale Rosc) Secara Batch. Skripsi tidak diterbitkan. Semarang: Jurusan Teknik Kimia Fakultas Teknik Universitas Diponegoro Semarang.

Sastroasmoro, S. 2010. Dasar-Dasar Metodologi Penelitian Klinis.CV Sagung Seto, Jakarta, hal. 292

Shamina, A. 2001. Secondary Metabolites in Black Pepper and Their Effect on The Foot-Rot Pathogen Phytophtora capsici. India

Shamkuwar, B., et al. 2013. Evaluation of Active Constituent of Piper nigrum in Diarrhoe. Government College of Pharmacy. India

Smita, et al. 2011. Extraction And Evaluation of Piperine From Piper nigrum Linn. India

USP 32. 2009. United State Pharmacopeia 32 National Formulary 27

Wagner, H. e al. 1996. Plant Drug Analysis A Thin LayerChromatography Atlas. Second Edition. Springer. Germany 
Penetapan Kadar Piperin Dalam Ekstrak....

WHO. 2000. General Guidelines for Methodologies on Research and Evaluation of Traditional Medicine. Geneva, p 1-2

Wood, A.B., 1988. Piperine Determination in Pepper (Piper nigrum L.) and Its Oleoresins A Reversed-Phase High Performance Liquid Chromatographic Method. London. Inggris 
Febriyanti AP, Iswarin SJ, Susanti, JIF Farmasyifa, 1(2): 69 - 79 